Ilmu Pertanian (Agricultural Science)

Vol. 1 No.1 April, 2016 : 001 - 006

Available online at http://journal.ugm.ac.id/jip

DOI: doi.org/10.22146/ipas.11654

ILMU PERTANIAN

(AGRICULTURAL SCIENCE)

\title{
Survey and Detection of Pectobacterium atrosepticum in Major Potato-Growing Areas in Central Java Province, Indonesia
}

\author{
Ismiyatuningsih ${ }^{1}$, Tri Joko ${ }^{2 *}$, Sedyo Hartono ${ }^{2}$ \\ ${ }^{1}$ Agency for Agricultural Quarantine Class I Semarang \\ Jln. M. Pardi no. 7, Kompleks Pelabuhan Tanjung Emas, Semarang, Central Java, 50174 \\ ${ }^{2}$ Department of Plant Protection, Faculty of Agriculture, Universitas Gadjah Mada \\ Jln. Flora no. 1, Bulaksumur, Sleman, Yogyakarta 55281 \\ *Corresponding email: tjoko@ugm.ac.id
}

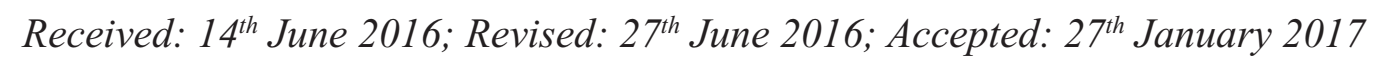

\begin{abstract}
Potato (Solanum tuberosum) is a seasonal shrub-tuber crop originated from sub-tropical area. Soft-rot is one of the most important diseases of potato. It can be caused by Pectobactorium atrosepticum, a pathogen within a status of quarantine plant pest A1 type I in Indonesia. The objective of this study was to know the incidence of potato soft rot disease and to detect $P$. atrosepticum in major potato-growing areas in Central Java Province by applying the serology method using DAS-ELISA technique. Survey of soft rot disease was carried out in some regencies in Central Java Province, i.e. Magelang, Banjarnegara, Wonosobo and Karanganyar. The field survey of potato plant in all the regencies indicated symptoms of stem rot which was black in color (blackleg) and foul-smelling, with disease incidence of about $10-90 \%$. The laboratory testing showed that by applying DAS-ELISA method, P. atrosepticum was detected in samples collected from Pandean and Bagongan villages, district of Ngablak,Regency of Magelang, Central Java Province.
\end{abstract}

Keywords: Detection, ELISA, Pectobacterium atrosepticum, Potato

\section{INTRODUCTION}

As one of the main sources of carbohydrate, potato is an important commodity. Compared to other types of horticultural commodity, it has the most opportunity for agribusiness and agriculture development (Anonym, 2011). Potato production in Indonesia is lower (only 16 ton/ha) than Europe, where the average achieved $10 \%$ of the national demand; $4.9 \%$ of it is supplied domestically and the rest is imported (Baharuddin et al., 2012). One of the constraints causing the low production in Indonesia is the soft rot and blackleg diseases. Soft rot is an important disease because it infects and causes severe disease to many types of vegetables, food, and ornamental crops (Joko et al., 2007a; 2007b). Soft rot disease causes major loss in worldwide agriculture. The cause of the disease is also reported to be spread from temperate, subtropics to tropical area (Perombelon and Kelman, 1980). It was reported in Orchidaceae that the soft rot disease in nursery with poor management can reach more than 50\% (Joko et al., 2011a; 2011b). Various species of pathogenic bacteria within families of Enterobacteriaceae and Pseudomonadaceae can be isolated from orchid plant with soft rot symptoms (Joko et al., 2014).

The main cause of rot to the stem base of the potato and the tubers that requires attention is Pectobacterium atrosepticum. Other than, $P$. atrosepticum, which is dominant in cold area, Dickeya spp.and P. carotovorum are well developed in warmer area (above $25^{\circ} \mathrm{C}$ ). They are also reported to cause rot in the trunk of potato plant (aerial rot) (Perombelon, 1992; Toth et al., 2003). P. atrosepticum is transmitted by the seed (seed-borne). This indicates that imported seed highly risky being entrance of pathogen into Indonesia. Efforts to trace the probability of the entrance through the imported tuber seed of $P$. atrosepticum can be done by detecting the existence of the pathogen in suspected area distribution of the imported seed.

It is important to take preliminary detection upon the existence of $P$. atrosepticum especially in imported seed being the entrance doors. This is to avoid the dispersion of the bacteria through the seed as the 
carrier media. Also, it requires continual monitoring of potato production centers in Indonesia to confirm the existence of $\mathrm{P}$. atrosepticum in the suspected area. Thus, a quick and accurate detection method is required. One of the mostly used is immunoassay. Various immunoassay methods are available; one of them is the Enzyme-Linked Immunosorbent Assay (ELISA). Immunoassay is a method to measure the unrefined substance using specific antibody. The enzyme used for the immunology indicator is the main characteristic of this technique (Burgess, 1995). This method is carried out by reacting the antiserum with the antigen of the microorganism. Antigen is used for identification due to its long lasting stability (Bowden, 1993). The objective of this study was to identify the soft rot disease incidence in potato plant centers in Central Java as well as to detect $P$. atrosepticum as the quarantine plant pest $\mathrm{A} 1$ type $\mathrm{I}$ by using the DAS-ELISA method.

\section{MATERIALS AND METHODS}

\section{Survey and Sampling}

The samples of the plant or part of the potato plant with symptoms of soft rot and blackleg diseases were collected from 9 locations within the 4 regencies of potato plant centers in Central Java. They were 1 . Patakbanteng village, district of Kejajar, regency of Wonosobo at 2,565 $\mathrm{m}$ above sea level (asl) (7' 12' 33'. 18' LS and 109' 55'25.44' BT); 2. Tieng village, district of Kejajar, regency of Wonosobo at 1,789 m asl (7 13'. 37.109'.41' LS and 109' 52' 110' 64 BT); 3. Kejajar village, district of Kejajar, regency of Wonosobo at 2,302 $\mathrm{m}$ asl ( $7^{\circ} 15^{\prime} 20^{\prime} \mathrm{LS}$ and 109' 47' 35 ' BT); 4) Buntu village, district of Batur, regency of Banjarnegara at $1,010 \mathrm{~m}$ asl (7' 16' 24' LS and 109' 57' 17' E); 5. Batur village, district of Sumberejo, regency of Wonosobo at 1,663 $\mathrm{m}$ asl (7' 12' 31' LS and 109' 29' 45' BT); 6. Gembol village, district of Pejawaran, regency of Banjarnegara at $1,150 \mathrm{~m}$ asl (7 14' 45' S 109 47' 47' E ); 7. Bagongan village, district of Ngablak, regency of Magelang at $1,500 \mathrm{~m}$ asl ( $\left.7^{\circ} 22^{\prime} 17^{\circ} 110^{\circ} 23^{\prime} 52^{\prime} \mathrm{E}\right)$; 8. Pandean village, district of Ngablak, regency of Magelang at 1,500 m asl (7' 19' 24' 9' LS and 110' 36' 36'. 0; BT); and 9. Segorogunung village, district of Argoyoso, regency of Karanganyar at $1,500 \mathrm{~m}$ asl $\left(7^{\circ} 36^{\prime} 37^{\prime} \mathrm{S} 111^{\circ} 7^{\prime}\right.$ $58^{\prime} \mathrm{E}$ ). The locations were selected based on the data where the potato plant commodity being the main host-plant. Observations were taken only on fields indicated with symptoms of soft rot and blackleg diseases under the purposive random sampling method. Survey and sampling were carried out two times in September 2012 and early January 2013. Samples included stem, trunk and tuber indicated with the symptoms of the diseases.

Samples were put on a paper and into an envelope before processed in the laboratory for serology assays (Joko et al., 2012).

\section{Calculating the Disease Incidence}

For each observed fields, 20 plants were selected with diagonal scouting and disease incidence was calculated (Wardhika et al., 2014). The age of the plant indicated disease symptom was recorded. The disease incidence can be calculated by using the following formula (Cooke, 2006):

$$
\text { Disease Incidence }=\frac{n}{N} \times 100 \%
$$

Disease Incidence is the percentage of plant infected by pathogen $(\mathrm{n})$ of the total observed plant $(\mathrm{N})$.

\section{Detecting the Pathogen using ELISA}

Samples of stems, trunks and tuber of the potato plant indicating unique symptom of soft rot or blackleg diseases were detected using the double anti sandwich enzyme-linked Immunosorbent assay (DAS-ELISA) with antiserum specific to $P$. atrosepticum. Of each location, three repetitions were made and the DAS-ELISA testing were based on the protocols made by the antiserum producer (Agdia, Inc.). Coating humid box was given with wet towel paper under it and ELISA plate was stored to maintain the evaporation. Before used, capture antibody was diluted by using the coating buffer. A $100 \mu 1$ antibody solvent was prepared and added into each plate well, incubated for 4 hours in room temperature and washed using the PBST. Samples with symptoms were extracted using the general buffer (GEB) within 1:10 ratio. A $100 \mu 1$ sample diluted for each testing well was divided into wells of $100 \mu \mathrm{l}$ positive control, $100 \mu 1$ negative control and 100 GEB of buffer well. Samples were incubated for 2 hours in room temperature, then the conjugate was diluted using ECI buffer and washed using the PBST solvent by adding $100 \mu 1$ conjugate to each plate well. The plate was incubated for 2 hours at room temperature and added with PNP solvent within concentration of $1 \mathrm{mg} / \mathrm{ml}$ of one tablet for $5 \mathrm{ml}$ of PNP solvent. It was put into plate well and incubated for 60 minutes.

Color intensity in the testing results was measured by using the ELISA reader at wave length of $405 \mathrm{~nm}$. Absorbance reading upon the sample using the ELISA reader was stated positive when the absorbency value of ELISA of the specimen sample 

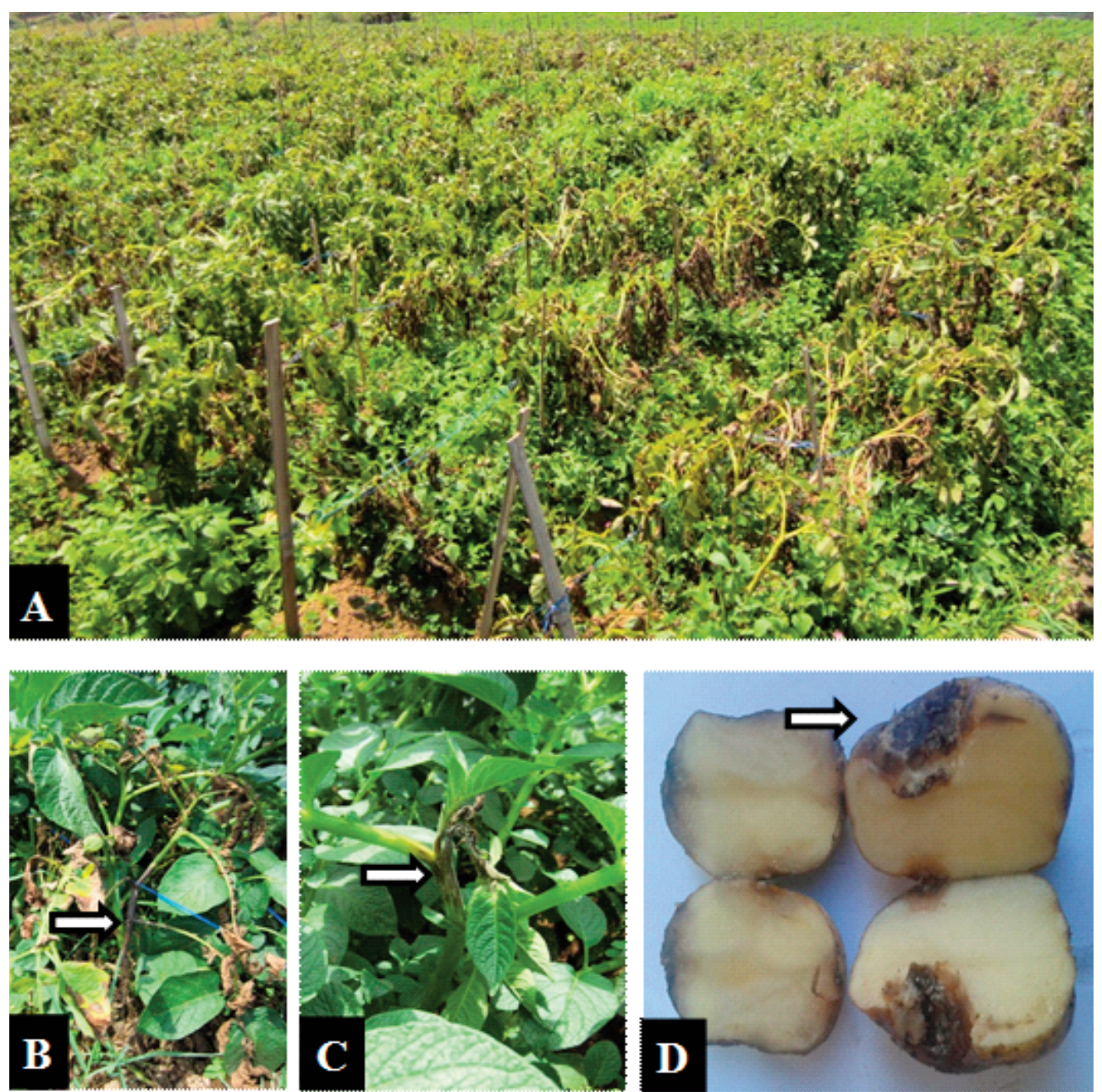

Figure 1. Symptoms of soft rot disease and blackleg in potato plant on the field (A). As indicated by arrow, the rot symptoms are visible in the stem (B) or can also experience rot in the trunk or tip of the infected plants (C), infected tuber shows soft rot symptom in blackish-brown color and produces foul-smelling aroma (D).

was larger or the same as 2 times of the average negative control (healthy plant) (Windari et al., 2015).

\section{RESULT AND DISCUSSION}

\section{Disease Symptoms on the Field}

The results of field survey upon the potato plant in all districts showed unique symptoms of soft rot, indicated from green turning yellow leaves with black color base-stem continued to tip of the plant. In most severe condition, it smelled strongly from the rotten wound. Plants infected by the disease would be withered and then died. Fields with severe infection showed mass wither with dried leaves and brownish color (Figure 1A). Infected plants showed early symptoms of lesion in the stem base of the plant. When the infection continued, it would cause lengthwise blackleg (Figure 1B), especially when the plant entered two months of age. Lesion could also occur on the top area of the trunk (aerial rot) (Figure 1C). Likewise, tuber in the plant with disease indicated unique symptom of soft rot and foulsmelling (Figure 1D). The development of soft rot disease was also worsening by the moist soil on the cultivation field in which the pathogen infection is spreading to the entire stem and led to dryness of the stem. Plant infected by pathogen would experience stunted growth that decreased the potato tuber product.

People in the cultivation location called the symptom of the disease as "liyer", referring the permanent withered condition. This disease is commonly found in regencies of Wonosobo and Banjarnegara as they are the production centers of potato plant where the people continually plant potato with no planting rotation. The soft rot bacterial pathogen can survive long time in the soil (soil-borne pathogen) where it promptly infects the plants being continually planted in the same field. When the host-plant is unavailable, bacteria can last by the plant debris. The social-culture of the surrounding people is leaving the plant debris on the field. Such behavior plays important role in extending the disease cycle. 
Table 1. Locations, age of the plant and disease incidence in potato plant

\begin{tabular}{|c|c|c|c|c|}
\hline \multirow{3}{*}{ Location } & \multicolumn{2}{|c|}{ Age of the Plant (months) } & \multicolumn{2}{|c|}{ Disease incidence $(\%)$} \\
\hline & \multicolumn{4}{|c|}{ Observation Observation Observation Observation } \\
\hline & I & II & $\mathbf{I}$ & II \\
\hline $\begin{array}{l}\text { Patakbanteng village, district of } \\
\text { Kejajar, reg. of Wonosobo }\end{array}$ & 3 & 3.5 & 60 & 80 \\
\hline $\begin{array}{l}\text { Kejajar village, district of Kejajar, } \\
\text { reg. of Wonosobo }\end{array}$ & 2 & 2.5 & 30 & 40 \\
\hline $\begin{array}{l}\text { Tieng village, district of Tieng } \\
\text { reg. of Wonosobo }\end{array}$ & 2.5 & 3 & 70 & 90 \\
\hline $\begin{array}{l}\text { Buntu village, district of Batur, } \\
\text { reg. of Banjarnegara }\end{array}$ & 3 & 3.5 & 10 & 45 \\
\hline $\begin{array}{l}\text { Batur village, district of Sum- } \\
\text { berejo, reg. of Banjarnegara }\end{array}$ & 2 & 2.5 & 40 & 65 \\
\hline $\begin{array}{l}\text { Gembol village, district of Pe- } \\
\text { jawaran, reg. of Banjarnegara }\end{array}$ & 2 & 2.5 & 60 & 70 \\
\hline $\begin{array}{l}\text { Bagongan village, district of } \\
\text { Ngablak, reg. of Magelang }\end{array}$ & 2 & 3 & 50 & 65 \\
\hline $\begin{array}{l}\text { Pandean village, district of } \\
\text { Ngablak, reg. of Magelang }\end{array}$ & 2 & 3 & 60 & 65 \\
\hline $\begin{array}{l}\text { Segorogunung village, district of } \\
\text { Argoyoso, reg. of Karanganyar }\end{array}$ & 2 & 3.5 & 50 & 75 \\
\hline
\end{tabular}

Table 2. DAS-ELISA results on infected samples collected from locations of potato plant production centers in Central Java

\begin{tabular}{lcc}
\hline \multicolumn{1}{c}{ Location } & ELISA I testing result & ELISA II testing result \\
\hline $\begin{array}{l}\text { Patakbanteng village, district of keja- } \\
\text { jar, reg. of Wonosobo }\end{array}$ & $(-)$ & $(-)$ \\
$\begin{array}{l}\text { Kejajar village, district of Kejajar, } \\
\text { reg. of Wonosobo }\end{array}$ & $(-)$ & $(-)$ \\
$\begin{array}{l}\text { Tieng village, district of Tieng, reg. } \\
\text { of Wonosobo }\end{array}$ & $(-)$ & $(-)$ \\
$\begin{array}{l}\text { Buntu village, district of Batur, reg. } \\
\text { of Banjarnegara }\end{array}$ & $(-)$ & $(-)$ \\
$\begin{array}{l}\text { Batur village, district of Sumberejo, } \\
\text { reg. of Banjarnegara }\end{array}$ & $(-)$ & $(-)$ \\
$\begin{array}{l}\text { Gembol village, district of Pe- } \\
\text { jawaran, reg. of Banjarnegara }\end{array}$ & $(-)$ & $(-)$ \\
$\begin{array}{l}\text { Bagongan village, district of } \\
\text { Ngablak, reg. of Magelang } \\
\text { Pandean village, district of Ngablak, } \\
\text { reg. of Magelang }\end{array}$ & $(+)$ & $(+)$ \\
$\begin{array}{l}\text { Segorogunung village, district of Ar- } \\
\text { goyoso, reg. of Karanganyar }\end{array}$ & $(+)$ & $(+)$ \\
Remarks: (+): infected; (-): not infected & $(-)$ & $(-)$
\end{tabular}

Table 3. Average absorbency value of ELISA at wavelength of $405 \mathrm{~nm}$

\begin{tabular}{cccccc}
\hline \multirow{2}{*}{ DAS-ELISA } & \multirow{2}{*}{ Buffer } & \multicolumn{4}{c}{ Average absorbency value of ELISA ( 405 nm) } \\
\cline { 3 - 6 } & & $\begin{array}{c}\text { Positive } \\
\text { Control }\end{array}$ & $\begin{array}{c}\text { Negative } \\
\text { Control }\end{array}$ & $\begin{array}{c}\text { Positive } \\
\text { Sample }\end{array}$ & $\begin{array}{c}\text { Negative } \\
\text { Sample }\end{array}$ \\
\hline I & 0.201 & 0.633 & 0.248 & $2.561-2.762$ & $0.111-0.270$ \\
II & 0.154 & 0.669 & 0.226 & $2.797-3.173$ & $0.108-0.380$ \\
\hline
\end{tabular}

\section{Disease Incidence}

Observed from various sampling locations, the disease incidence varied between $10-90 \%$ as well as in various age of the plant. Location with the highest incidence was Tieng village, Tieng district, Wonosobo, and the lowest was Buntu village, Batur district, Banjarnegara (Table 1).
Based on the table 1, the average age of the plants indicating symptom of disease was between 2-3.5 months and found in every district. Averagely, the potato plant was infected by soft rot pathogen during the vegetative period when the plant required water for the growth of the root, stem, and leaves. As soon as the plant showed the symptom during this phase, 
it would experience stunted growth. If infection occured during the generative phase, when the plant experienced growth for the flowering period and tuber development, it would experience stunted flowering with small tuber. Such condition commonly happens in the regency of Wonosobo and Banjarnegara.

\section{Detecting $P$. atrosepticum using the DAS-ELISA method}

Serology method of DAS-ELISA was carried out upon samples collected from the field. The assay was taken twice at different times based on the time of survey. Samples with symptom were cut and crushed finely to be used as the antigen because $P$. atrosepticum exists in the tissue of the infected plant. Based on the DAS-ELISA assays (Table 2), two samples originated from two different locations (Pandean and Bagongan villages, district of Ngablak, Magelang) were positively infected by $P$. atrosepticum indicated by the changing of color of the samples compared to that of uncolored buffer. To determine the absorbency value, the color changing was read three times. The positive control was a solvent with identified antigen concentration. Absorbency resulted from the positive control was used as the indicator.

A sample is stated as positive based on DASELISA when the absorbency value at wavelength of $405 \mathrm{~nm}$ is close to the absorbency value of the positive control, or twice or more than the absorbency value of the control buffer. DAS-ELISA assay was carried out twice (Table 3). Samples of infected plant collected from Pandean and Bagongan villages, district of Ngablak, Magelang were indicated positively with infection of $P$. atrosepticum at average ELISA absorbent value of 2,561-2,762 in assay I and 2,797-3,173 in assay II.

In this study, it was showed that in potato production centers in Central Java, i.e. the regencies of Wonosobo, Banjarnegara, Magelang, and Karanganyar, soft rot and blackleg diseases were found. However, based on the serological analysis using the DASELISA method, it was identified that only samples from the regency of Magelang was detected with $P$. atrosepticum infection, and samples collected from the regencies of Wonosobo, Banjarnegara, and Karanganyar were not. This indicated that the soft rot and blackleg diseases in potato were able to be infected by the bacteria other than P. atrosepticum. Czajkowski et al. (2011), reported that Dickeya spp. and Pectotobacterium carotovorum are members of soft-rot enterobacteriaceae that can cause soft rot disease on many host-plants including potato.
Meanwhile, $P$. atrosepticum is a bacterial pathogen with very specific host, i.e. in potato plant. $P$. atrosepticum can not survive more than a year in the soil except in the potato tuber or in infected plants (Diallo et al., 2009).

Indication of the existence of $P$. atrosepticum in Magelang regency should be further studied by confirmation using the PCR technique. This is in line to the study by Haerani et al. (2015) that the production centers of potato in Pangalengan, Garut, Dieng and Malang had been infected by Dickeya sp. based on the ELISA analysis. But when conformed by using the PCR using specific primer, the results were negative. Serology assay by using polyclonal antiserum was reported to evenly cross reaction to bacteria with close genetic relationship (Emantoko, 2001). It is valuable only for the early sreening of the target bacteria. Thus, the $P$. atrosepticum status as quarantine plant pathogen A1 type I for potato plant should be further considered and its existence requires awareness. Results of this study also support the efforts taken by the Indonesian Agency for Agricultural Quarantine which still gives quarantine plant pathogenas A1 status to $P$. atrosepticum.

\section{CONCLUSION}

ELISA-based survey of $P$. atrosepticum in Central Java revealed that the pathogen was detected in Magelang regency; however the result of this study indicated that the occurrence was found only in limited potato-growing areas.

\section{ACKNOWLEDGMENT}

We acknowledge Agency for Agricultural Quarantine Class I Semarang for the supports of research facilities and to Mr. Heru Wahyupraja for his supports in the completion of this study.

\section{REFERENCES}

Anonim. 2011. Petunjuk Teknis Pemantauan Daerah Sebar OP/OPTK. Balai Karantina Pertanian Kelas I. Semarang. Pp: 1-30.

Baharuddin, Kuswinanti T, Lamba SE. 2012. Percepatan Ketersediaan Benih Kentang Unggulan Melalui Introduksi Paket Bioteknologi Ramah Lingkungan di Kabupaten Toraja Utara. Dalam: Prosiding InSINas; 2012 Nov 29-30; Bogor (ID): Institut Pertanian Bogor. hlm 336-344.

Bowden, G.H.W. 1993. Serological Identification. Academic Press, London.

Burgess, G.W. 1995. Prinsip Dasar Elisa dan Variasi Konfigurasinya, dalam Teknologi Elisa dalam 
Diagnosis dan Penelitian. Ed.Graham W. Burgess. Yogyakarta: Gadjah Mada University Press. Hal 50-59.

Cooke, B.M., 2006. Disease Assessment and Yield Loss. In: Cooke, B.M., D.G. Jones and B. Kaye (eds.), The Epidemiology of Plant Diseases, 2nd edition, pp: 43-80. Springer, The Netherlands.

Czajkowski, R., M.C.M. Pérombelon, J.A. van Veen, J.M. van der Wolf. 2011. Control of blackleg and tuber soft rot of potato caused by Pectobacterium and Dickeya species: a review. Plant Pathology 60 (6): 999-1013.

Diallo, S. Latuar, X. Groboillot, A. Smadja, B. Copin, P. Orange, N. Feuilloley, J. Chevaliner, S. 2009. Simultaneous and Selective Detection of Two Major Soft Rot Pathogens of Potato; Pectobactorium atrosepticum (Erwiniacarotovora subsp. atrosepticum) and Dickeya spp. (Erwinia chrysanthemi). Eur. Journal of Plant Pathol. 125 : 349-354.

Emantoko S. 2001. Antibodi rekombinan: perkembangan terbaru dalam teknologi antibodi. Unitas. 9(2):29-43.

Haerani, A.N. Nawangsih, T.A. Damayanti. 2015. Deteksi dan Identifikasi Dickeya sp. Sebagai Organisme Penganggu TumbuhanKarantina A2 pada tanaman kentang di Jawa. Jurnal Fitopatologi Indonesia 11 (4): 105-112.

Joko, T., H. Hirata, S. Tsuyumu. 2007a. Sugar transporter (MfsX) of major facilitator superfamily is required for flagella-mediated pathogenesis in Dickeya dadantii 3937. Journal of General Plant Pathology 73: 266-273.

Joko, T., H. Hirata, S. Tsuyumu. 2007b. A sugar transporter (Mfs X) is also required by Dickeya dadantii 3937 for in planta fitness. Journal of General Plant Pathology 73:274-80.

Joko, T., N. Kusumandari, S. Hartono. 2011a. Optimasi Metode PCR untuk Deteksi Pectobacterium carotovorum, Penyebab Penyakit Busuk Lunak Anggrek. Jurnal Perlindungan
Tanaman Indonesia, 17 (2): 54-59.

Joko T, Kiswanti D, Hanudin, Subandiyah S. 2011b. Occurence of bacterial soft-rot of Phalaenopsis orchids in Yogyakarta and West Java, Indonesia. Proceeding of Internasional Seminar on "Natural Resources, Climate Change,danFood Security in Developing Countries". 2728 June 2011. Surabaya, Indonesia. P. 255-265.

Joko, T., M.P. Koentjoro, S. Somowiyarjo, M.S. Rohman, A. Liana, N. Ogawa. 2012. Response of Rhizobacterial Communities in Watermelon to Infection with Cucumber Green Mottle Mosaic Virus as Revealed by Cultivation-Dependent RISA. Archives of Phytopathology and Plant Protection, 45 (15): 1810-1818

Joko, T., A. Subandi, N. Kusumandari, A. Wibowo, A. Priyatmojo. 2014. Activities of Plant Cell Wall Degrading Enzymes by Bacterial Softrot of Orchid. Archives of Phytopathology and Plant Protection, 47 (10): 1239-1250.

Kamil, J. 1986. Teknologi Benih 1. Angkasa Raya. Pp 1-227.

Perombelon, M.C.M. 1992. Potato Blackleg: Epidemology, Host-Pathogen interaction and Control. Netherland Journal of Plant Pathology, 98: $135-146$.

Perombelon M.C.M.and Kelman A. 1980. Ecology of the soft rot erwinias. Annu Rev Phytopathol 18:361-367.

Toth I.K., Bell K.S., Holeva M.C., Birch P.R.J. 2003 Soft rot erwiniae: from genes to genomes. Mol Plant Path 4:17-30.

Wardhika, C.M., Suryanti, T. Joko. 2014. Eksplorasi Bakteri Agens Pengendali Hayati Fusarium solani dan Meloidogyne incognita pada Lada. Jurnal Perlindungan Tanaman Indonesia, 18 (2): 90-95. 